\title{
Enhanced Production of Soluble Pyrococcus furiosus a-Amylase in Bacillus subtilis through Chaperone Co-Expression, Heat Treatment and Fermentation Optimization
}

Kang Zhang ${ }^{1,2,3}$, Ruiting Tan ${ }^{1,2,3}$, Dongbang Yao ${ }^{1,2,3}$, Lingqia Su ${ }^{1,2,3}$, Yongmei Xia ${ }^{1}$, and Jing $\mathrm{Wu}^{1,2,3 *}$

'State Key Laboratory of Food Science and Technology, Jiangnan University, Wuxi 214122, P.R. China

${ }^{2}$ School of Biotechnology and Key Laboratory of Industrial Biotechnology, Ministry of Education, Jiangnan

University, Wuxi 214122, P.R. China

${ }^{3}$ International Joint Laboratory on Food Safety, Jiangnan University, Wuxi 214122, P.R. China

Pyrococcus furiosus a-amylase can hydrolyze a-1,4 linkages in starch and related carbohydrates under hyperthermophilic condition $\left(\sim 100^{\circ} \mathrm{C}\right)$, showing great potential in a wide range of industrial applications, while its relatively low productivity from heterologous hosts has limited the industrial applications. Bacillus subtilis, a gram-positive bacterium, has been widely used in industrial production for its non-pathogenic and powerful secretory characteristics. This study was conducted to increase production of $P$. furiosus $\alpha$-amylase in $B$. subtilis through three strategies. Initial experiments showed that co-expression of $P$. furiosus molecular chaperone peptidyl-prolyl cis-trans isomerase through genomic integration mode, using a CRISPR/Cas9 system, increased soluble amylase production. Therefore, considering that native $P$. furiosus $\alpha$-amylase is produced within a hyperthermophilic environment and is highly thermostable, heat treatment of intact culture at $90^{\circ} \mathrm{C}$ for $15 \mathrm{~min}$ was performed, thereby greatly increasing soluble amylase production. After optimization of the culture conditions (nitrogen source, carbon source, metal ion, temperature and $\mathrm{pH})$, experiments in a 3-L fermenter yielded a soluble activity of 3,806.7 $\mathrm{U} / \mathrm{ml}$, which was 3.3- and 28.2-fold those of a control without heat treatment $(1,155.1 \mathrm{U} / \mathrm{ml})$ and an empty expression vector control $(135.1 \mathrm{U} / \mathrm{ml})$, respectively. This represents the highest $P$. furiosus $a$-amylase production reported to date and should promote innovation in the starch liquefaction process and related industrial productions. Meanwhile, heat treatment, which may promote folding of aggregated $P$. furiosus a-amylase into a soluble, active form through the transfer of kinetic energy, may be of general benefit when producing proteins from thermophilic archaea.

Received: February 1, 2021 Accepted: March 22, 2021

First published online: March 23, 2021

*Corresponding autho Phone: 86-510-85327802 Fax: 86-510-85326653

E-mail: jingwu@jiangnan.edu.cn

Supplementary data for this paper are available on-line only at http://jmb.or.kr.

pISSN 1017-7825 elSSN 1738-8872

Copyright(C) 2021 by The Korean Society for Microbiology and Biotechnology
Keywords: a-Amylase, Bacillus subtilis, chaperone, heat treatment, 3-L fermenter cultivation

\section{Introduction}

Alpha-amylase (E.C. 3.2.1.1) is an enzyme that catalyzes the hydrolysis of $\alpha-1,4$ linkages in starch and related carbohydrates and has been widely applied in starch processing, baking, brewing and the de-sizing of textiles [13]. In industrial starch processing, $\alpha$-amylases are used in the liquefaction step to hydrolyze starch into glucose oligomers. The ideal temperature and $\mathrm{pH}$ for this step are $105^{\circ} \mathrm{C}$ and $\mathrm{pH} 4.5$, respectively. Since 1980, Bacillus licheniformis $\alpha$-amylase has been the main enzyme used in starch liquefaction. This enzyme exhibits optimal activity at $90^{\circ} \mathrm{C}$ and $\mathrm{pH} 6.0$, which can only partly satisfy the starch liquefaction requirement [4-6]. Hyperthermophilic enzymes exhibit optimal activity at temperatures higher than $90^{\circ} \mathrm{C}$. Most of these enzymes come from thermophilic archaea, like Pyrococcus furiosus, Thermococcus kodakarensis and Sulfolobus solfataricus, while the remainder come from thermophilic bacteria [7-9]. P. furiosus a-amylase is a hyperthermophilic enzyme that exhibits optimal activity at about $100^{\circ} \mathrm{C}$, where it has a half-life of more than $12 \mathrm{~h}[10,11]$. In addition to its excellent thermostability, P. furiosus $\alpha$-amylase exhibits optimal activity at a $\mathrm{pH}$ of about 5.6, with good stability and no less than $80 \%$ of optimal activity at $\mathrm{pH}$ values from 4.5 to 6.5 . These characteristics make P. furiosus $\alpha$-amylase potentially suitable for industrial applications.

P. furiosus $\alpha$-amylase has been known and characterized since 1990, but the relatively low level of heterologous expression has limited its industrial application [2]. When produced in Escherichia coli, P. furiosus a-amylase is 
prone to form inclusion bodies. Thus, the highest reported yield has been $11.4 \mathrm{U} / \mathrm{ml}$ [12]. P. furiosus $\alpha$-amylase is also prone to form inclusion bodies when produced in Bacillus using a signal peptide with low secretion efficiency. When using a signal peptide with high secretion efficiency, $P$. furiosus $\alpha$-amylase is prone to be degraded by the quality control proteases $\mathrm{HtrA} / \mathrm{HtrB}$, or the remaining extracellular proteases, because it folds slowly after translocation across the cytoplasmic membrane [12-14]. When produced in Bacillus subtilis and Bacillus amyloliquefaciens, the highest reported yields have been 0.7 and 2,714 $\mathrm{U} / \mathrm{ml}$, respectively. The highest reported production of $P$. furiosus a-amylase in yeast yielded $220 \mathrm{U} / \mathrm{ml}$ [15]. The relatively low production levels of

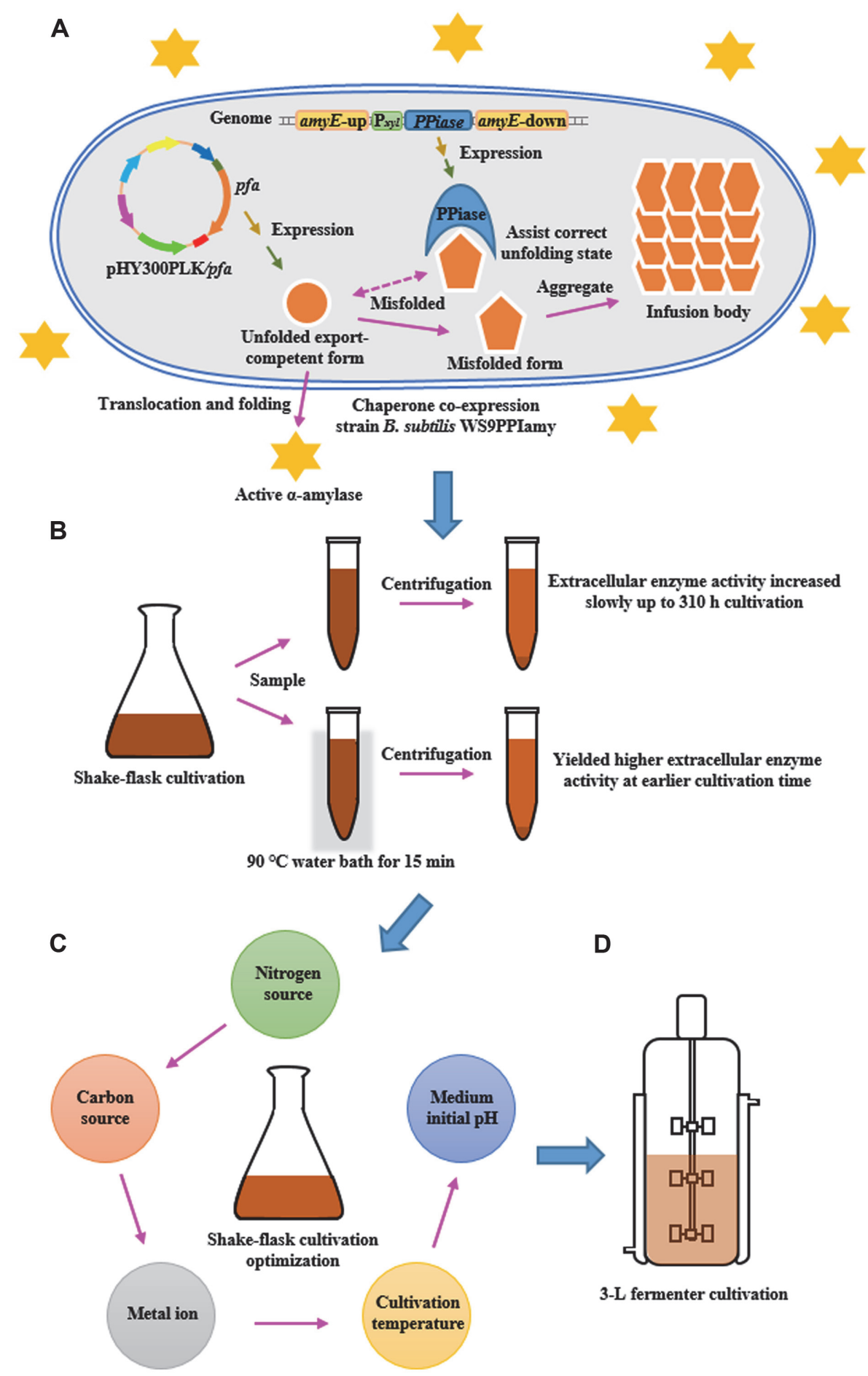

Fig. 1. Scheme of strategies used to improve P. furiosus $\alpha$-amylase production in B. subtilis. (A) Co-expression of molecular chaperone from thermophilic archaea in B. subtilis. (B) Heat treatment of the CB. (C) Shake-flask cultivation optimization. (D) 3-L fermenter cultivation. 
P. furiosus $\alpha$-amylase in these mesophilic host strains may be caused by poor protein folding in these strains.

Thermophilic archaea and mesophilic prokaryotic and eukaryotic microbes all express molecular chaperone systems that assist protein folding, but they differ in type, structure, and number [16, 17]. For instance, they all contain ATP-dependent chaperonins of similar structure (two stacked, back-to-back rings), but the kind and number of subunits in the rings are different [18]. Furthermore, prefoldins are a kind of important molecular chaperones that direct unfolded or misfolded proteins to chaperonins for correct folding. They exist as a heterohexameric assembly with a jellyfish-like structure and function in an ATP-independent manner. Prefoldins have been found only in archaea and eukaryotic microbes [19,20]. A novel prefoldin recently found in Methanocaldococcus jannaschii, a thermophilic archaean, is a homohexamer that assembles into a filamentous structure. This protein exhibits activity similar to those of the hetero-hexameric prefoldins $[21,22]$. Peptidyl-prolyl cis-trans isomerase (PPIase) is another important type of chaperone. These enzymes catalyze the cis-trans isomerization of prolyl imide bonds in protein, which is a rate-limiting step in protein folding [23]. PPIases have been found in archaea as well as prokaryotic and eukaryotic microbes $[24,25]$. These differences among the chaperone systems of thermophilic archaea, mesophilic prokaryotic and eukaryotic microbes may be among the reasons for the poor folding of thermophilic archaeal enzymes like P. furiosus a-amylase in commonly used mesophilic prokaryotic and eukaryotic host strains.

Many strategies have been employed to convert the P. furiosus $\alpha$-amylase inclusion bodies produced in E. coli into soluble, active enzyme. They include co-expression of heterologous chaperones, like $P$. furiosus prefoldins, chaperonins and small heat shock proteins, and overexpression of homologous chaperones like GroEL/GroES. Both of these strategies have been shown to reduce the level of inclusion body formation and increase soluble activity, but co-expression of $P$. furiosus prefoldins has given the best results [26]. Other strategies include solubilization of the inclusion bodies found within cells disrupted using ultrasound. This has been accomplished through heat treatment or glycerol extraction of the sediment, followed by purification through Phenyl Sepharose chromatography, which cannot be scaled up for industrial production [27, 28]. Even when the production bottleneck of $E$. coli is improved using these methods, E. coli presents a food safety issue that restricts its application in the food processing industry.

$B$. subtilis shows great potential for the production of $P$. furiosus $\alpha$-amylase because it is non-pathogenic, has powerful secretory ability and can be grown to high cell density $[29,30]$. In our previous study (unpublished), P. furiosus a-amylase production in B. subtilis was improved from 18.3 to $135.1 \mathrm{U} / \mathrm{mL}$ through signal peptide optimization and overexpression of the extracellular chaperone PrsA. However, even in this system substantial amounts of inclusion bodies could be found in the cytoplasm. In this study, $P$. furiosus $a$-amylase production in B. subtilis was improved using three strategies (Fig. 1). Firstly, co-expression of molecular chaperones from thermophilic archaea was assessed. Then, heat treatment of the culture broth (CB) was investigated. The heattreated samples exhibited higher soluble activity and their own extraordinary stability, like that of untreated extracellular enzyme, during storage. Finally, shake-flask cultivation conditions were optimized and production was scaled up to a 3-L fermenter.

\section{Materials and Methods \\ Materials}

Yeast extract powder 1, industrial yeast extract powder 2 and peptone 1 were purchased from Angie Yeast Co., Ltd. (China). Soy meal 1 was purchased from Shandong Longkete Enzyme Preparations Co., Ltd. (China). Soy peptone and soy meal 2 were purchased from Xi Wang Co., Ltd. (China). Yeast extract, peptone, industrial peptone, fish meal peptone, beef extract fermentation, cottonseed meal, bone peptone, tryptone, beef meal, corn steep powder, yeast extract fermentation and beef peptone were purchased from Sinopharm Chemical Reagent Co., Ltd. (China).

\section{Strains and Plasmids}

The strains and plasmids used in this study are listed in Table 1. E. coli JM109 was used as the cloning host for routine plasmid construction. Construction of B. subtilis WS9, used as an expression host and stored in our library, has been described in the literature [31]. The P. furiosus a-amylase expression plasmid pHY300PLK/pfa, which contains the dual promoter $\mathrm{P}_{H p a I I}-\mathrm{P}_{a m y \text { Q }}$ a mutant $B$. subtilis signal peptide AspB (Table S1), and a codonoptimized (B. subtilis codon usage) $\alpha$-amylase gene (GenBank No. MT988065), were constructed previously and stored in our laboratory (Fig. S1 and Table S2). P. furiosus a-amylase-producing strain B. subtilis WS9amy, constructed through transforming plasmid pHY300PLK/pfa into B. subtilis WS9, was stored in our laboratory. Codon-optimized (B. subtilis codon usage) M. jannaschii prefoldins gene (GenBank No. MT988066, Table S2) and $P$. furiosus PPIase gene (GenBank No. MT988067, Table S2) were synthesized and inserted into cloning vector pMD18-T. Construction of the CRISPR/Cas9 disruption plasmid pHYcas9dapr has been described in the literature [32].

\section{Growth Media and Transformation}

LB medium containing (g/l) $\mathrm{NaCl} 10$, peptone 10, and yeast extract 5, was used for routine E. coli JM109 and B. subtilis cultivation. TB medium containing (g/l) $\mathrm{KH}_{2} \mathrm{PO}_{4} 2.3, \mathrm{~K}_{2} \mathrm{HPO}_{4} 16.4$, glycerol 5, yeast extract 24, and peptone 12 , was used for $B$. subtilis shake-flask fermentation. The medium used for 3-L fermenter cultivation contained (g/l) soy peptone 18 , yeast extract powder 9, glucose $5,\left(\mathrm{NH}_{4}\right)_{2} \mathrm{SO}_{4} 2.7,\left(\mathrm{NH}_{4}\right)_{2}-\mathrm{H}$-citrate $1, \mathrm{NaH}_{2} \mathrm{PO}_{4} \cdot \mathrm{H}_{2} \mathrm{O}$ 4, $\mathrm{K}_{2} \mathrm{HPO}_{4}$ 14.6, $\mathrm{MgSO}_{4} \cdot 7 \mathrm{H}_{2} \mathrm{O} 1, \mathrm{Na}_{2} \mathrm{SO}_{3} 2, \mathrm{AlCl}_{3} 0.4$, and trace element solution $3 \mathrm{ml} / \mathrm{l}$ [33]. The trace element solution contained (g/l) $\mathrm{CaCl}_{2} 0.5, \mathrm{ZnSO}_{4} \cdot 7 \mathrm{H}_{2} \mathrm{O} 0.18, \mathrm{MnSO}_{4} \cdot \mathrm{H}_{2} \mathrm{O} 0.1, \mathrm{Na}_{2}$-EDTA $10.05, \mathrm{FeCl}_{3} 8.35, \mathrm{CuSO}_{4} \cdot 5 \mathrm{H}_{2} \mathrm{O}$ 
Table 1. Strains and plasmids used in this study.

\begin{tabular}{|c|c|c|}
\hline Strain or plasmid & Characteristics & Sources \\
\hline \multicolumn{3}{|l|}{ Strains } \\
\hline E. coli JM109 & $\begin{array}{l}\text { supE } 44, \text { recA1, thi, endA } 1, \text { gyrA96, hsdR17 } \Delta(\text { lac-proAB }) / \mathrm{F}^{\prime}[\text { lacZ } \Delta \mathrm{M} 15 \text {, } \\
\left.\text { traD36, lacI }{ }^{q} \text {, proAB } B^{+}\right]\end{array}$ & Takara \\
\hline B. subtilis WS9 & $\begin{array}{l}\text { Derived from an undomesticated strain, } \Delta s r f C, \Delta s p o I I A C, \Delta n p r E, \Delta a m y E \text {, } \\
\Delta a p r E, \Delta n p r B, \Delta b p r, \Delta m p r, \Delta e p r\end{array}$ & {$[31]$} \\
\hline B. subtilis WS9pre & B. subtilis WS9 derivative, amyE:: $\mathrm{P}_{x y l}$-prefoldins & This work \\
\hline B. subtilis WS9PPI & B. subtilis WS9 derivative, amyE:: $\mathrm{P}_{x y l}-$ PPIase & This work \\
\hline B. subtilis WS9amy & B. subtilis WS9 contains recombinant plasmid pHY300PLK/pfa & This lab \\
\hline B. subtilis WS9preamy & B. subtilis WS9din contains recombinant plasmid $\mathrm{pHY} 300 \mathrm{PLK} / p f a$ & This work \\
\hline B. subtilis WS9PPIamy & B. subtilis WS9PPI contains recombinant plasmid pHY300PLK/pfa & This work \\
\hline \multicolumn{3}{|l|}{ Plasmids } \\
\hline pMD18-T & Amp ${ }^{\mathrm{r}}$, cloning vector & Takara \\
\hline pET24a & $\operatorname{Kan}^{\mathrm{r}}$, E. coli expression vector & Takara \\
\hline $\mathrm{pHY300PLK/pfa}$ & $\begin{array}{l}\operatorname{Amp}^{\mathrm{r}}\left(\text { E. coli), } \text { Tet }^{\mathrm{r}}(\text { B. subtilis and E. coli), P. furiosus } \alpha \text {-amylase recombinant }\right. \\
\text { expression plasmid }\end{array}$ & This lab \\
\hline $\mathrm{pBE}-\mathrm{S} 194 / p r s A$ & $\begin{array}{l}\operatorname{Amp}^{\mathrm{r}}\left(\text { E. coli), } \operatorname{Tet}^{\mathrm{r}}\left(\text { B. subtilis and E. coli), promoter } \mathrm{P}_{a p r} \text { PrsA overexpression }\right.\right. \\
\text { plasmid }\end{array}$ & {$[44]$} \\
\hline pHYcas9dapr & $\begin{array}{l}\operatorname{Amp}^{\mathrm{r}}\left(\text { E. coli), } \operatorname{Tet}^{\mathrm{r}} \text { (B. subtilis and E. coli), sgRNA and homologous repair }\right. \\
\text { template of aprE gene, CRISPR/Cas9 disruption plasmid }\end{array}$ & {$[32]$} \\
\hline pHYcas9pre & $\begin{array}{l}\operatorname{Amp}^{\mathrm{r}} \text { (E. coli), } \operatorname{Tet}^{\mathrm{r}} \text { (B. subtilis and E. coli), sgRNA of amyE gene, M. jannaschii } \\
\text { prefoldins gene insertion plasmids }\end{array}$ & This work \\
\hline pHYcas9PPI & $\begin{array}{l}\operatorname{Amp}^{\mathrm{r}}\left(\text { E. coli), } \text { Tet }^{\mathrm{r}} \text { (B. subtilis and E. coli), sgRNA of amyE gene, P. furiosus }\right. \\
\text { PPIase gene insertion plasmids }\end{array}$ & This work \\
\hline
\end{tabular}

0.16 , and $\mathrm{CoCl}_{2} \cdot 6 \mathrm{H}_{2} \mathrm{O}$ 0.18. The feeding solution used for 3- $\mathrm{L}$ fermenter cultivation contained (g/l) glucose 500, soy peptone 66.7 , yeast extract powder $33.3, \mathrm{MgSO}_{4} \cdot 7 \mathrm{H}_{2} \mathrm{O} 7.9$, and trace element solution $40 \mathrm{ml} / \mathrm{l}$. The media described were supplemented with $100 \mathrm{mg} / \mathrm{l}$ ampicillin or $20 \mathrm{mg} / \mathrm{l}$ tetracycline as needed. Expression plasmid and CRISPR/Cas9 gene insertion plasmid were transformed into B. subtilis using the chemical method of Anagnostopoulos and Spizizen, which is based on the mechanism whereby B. subtilis cell membrane and cell wall form defects under the effects of transformation cultivation medium and condition [34].

\section{Cultivation Conditions}

Shake-flask cultivations. For routine plasmid construction and seed culture, E. coli JM109 or B. subtilis strains in $10 \mathrm{ml}$ or $50 \mathrm{ml}$ of LB medium were inoculated with a $0.2 \%(\mathrm{v} / \mathrm{v})$ portion of inoculum, and then cultivated at $37^{\circ} \mathrm{C}$ and $200 \mathrm{rpm}$ for $10 \mathrm{~h}$. For shake-flask fermentation, $50 \mathrm{ml}$ of TB medium was inoculated with a 5\% (v/v) portion of the seed culture described above and cultivated at $37^{\circ} \mathrm{C}$ and $200 \mathrm{rpm}$ for $2 \mathrm{~h}$, and then $33^{\circ} \mathrm{C}$ and $200 \mathrm{rpm}$ for $60 \mathrm{~h}$.

3-L fermenter cultivations. A 3-L fermenter (Labfors, Infors-HT Co., Switzerland) containing 0.9 L of fermentation medium was inoculated with a $10 \%(\mathrm{v} / \mathrm{v})$ portion of seed culture. After inoculation, the dissolved oxygen (DO) decreased slowly from $100 \%$, and when it fell below $30 \%$, the impeller speed was automatically adjusted between 300 and $700 \mathrm{rpm}$, and pure oxygen was automatically injected into the fermenter as needed to maintain the DO at about 30\%. Approximately about $7 \mathrm{~h}$ after inoculation, the DO exhibited a sudden increase, indicating that the glucose in the medium had been nearly exhausted and feeding solution should be added. The feeding rate was increased slowly from 2 to $9 \mathrm{ml} / \mathrm{h}$, such that the glucose concentration remained below $0.5 \mathrm{~g} / \mathrm{l}$. The glucose concentration was measured with a SBA-40C biosensor (Biology Institute of Shandong Academy of Sciences, Jinan, China). The temperature was kept at $33^{\circ} \mathrm{C}$, and the $\mathrm{pH}$ was maintained at 7.0 through the addition of $\mathrm{NH}_{4} \mathrm{OH}$ and $20 \%(\mathrm{v} / \mathrm{v}) \mathrm{H}_{3} \mathrm{PO}_{4}$. Tetracycline $(20 \mathrm{mg} / \mathrm{l})$ was added every $48 \mathrm{~h}$ and antifoam was added as needed. Culture samples were collected at certain times.

\section{Construction of CRISPR/Cas9 Gene Insertion Plasmids and Chaperone Co-Expression Strains}

The primers used in this study are listed in Table 2. Plasmid pBE-S194/prsA2 was constructed through replacing the original promoter of plasmid pBE-S194/prsA $\left(\mathrm{P}_{a p r}\right)$ with the xylose-inducible promoter $\mathrm{P}_{x y l}$ (Fig. S2A). This was accomplished by using primer pair P01/P02 to amplify $\mathrm{P}_{x y l}$ and primer pair P03/P04 to amplify the rest of pBES194/prsA. The fragments were combined by using the OneStep Cloning Kit (Vazyme, China). Plasmid pBES194/prsA2 contains a MluI site upstream and a SacI downstream of the prsA gene. Genes encoding M. jannaschii prefoldins and P. furiosus PPIase were inserted into cloning vector pMD18-T, which contains an MluI site upstream and a SacI site downstream of the inserted sequence. These sites were used to excise the desired genes and replace the prsA gene in the plasmid pBE-S194/prsA2, yielding plasmids pBE-S194/pre and pBE-S194/PPI, respectively.

CRISPR/Cas9 gene insertion plasmids pHYcas9pre and pHYcas9PPI were constructed by replacing the N20 sequence and homologous repair template of CRISPR/Cas9 disruption plasmid pHYcas9dapr. The N20 sequence of pHYcas9dapr was replaced through inverse PCR with primer pair P05/P06, yielding plasmid pHYcas9damy1. The nucleotide sequences of the promoter $\mathrm{P}_{x y}$, the prs $A$ gene and the terminator were inserted between the 
Table 2. Primers used in this study.

\begin{tabular}{cl}
\hline Primers & \multicolumn{1}{c}{ Sequence $\left(5^{\prime}-3^{\prime}\right)^{\mathrm{a}}$} \\
\hline P01 & ACGTTTTTAAAGGCTTTTAAATCAACGTGATATAGGTTTGCTAACC \\
P03 & GCGATTTTCTTCATACGCGTTGTACATTCACCTCCTTGATTAAGTG \\
P04 & ACGCGTATGAAGAAAATCGC \\
P05 & CCATAAAGCTTTAAAAACGTTTTAAGG \\
P06 & ATTCCATGCATGAAGAATGGTTATATTTTACATAATCGCGCGC \\
P07 & CGGAACCATTCTTCATGCATATCAACGTGATATAGGTTTGCTAACC \\
P08 & TAACGTATTGAACGACCCCCGGCAGTACCGGCATA \\
P09 & ATAAGAATGCGGCCGCCTGCGTAATAGACTTTCAGGCGT \\
P10 & CTATATCACGTTGATATGCATGAAGAATGGTTCCGC \\
P11 & ATAGTTTAGCGGCCGCCGTACTGCCTGAACGAGAAGC \\
P12 & TATGCCGGTACTGCCGGGGGTCGTTCAATACGTTAAAACACAA \\
P13 & CTTTGCCCAAGCTTCTAGACTGCGTAATAGACTTTCAGGCG \\
P14 & GCTCAATGTTTTCAGCCAGCGTACTGCCTGAACGAGAAGC \\
P15 & CTGGCTGAAAACATTGAGCCTTTGA \\
P16 17 & TCTAGAAGCTTGGGCAAAGCGTTTTC \\
P18 & GTAACATGTAAGCCATAAGCCATTCG \\
\hline
\end{tabular}

${ }^{a}$ The nucleotide sequences of restriction enzyme sites were underlined.

upstream and downstream segments of amyE homologous repair templates through overlap PCR with primer pairs P07/P08, P09/P10 and P11/P12, respectively. The overlap nucleotide sequence was then ligated into the NcoI restriction site of plasmid pET24a, yielding plasmid pET24a/prsA. The homologous repair template in plasmid pET24a/prs A was amplified using primer pair P13/P14 and was used to replace the original homologous repair template of pHYcas9damy1, yielding plasmid pHYcas9prsA, of which the other part of pHYcas9damyl was amplified using primer pair P15/P16. Then, the nucleotide sequences of promoter $\mathrm{P}_{x y l}$, prefoldins or PPIase encoding gene and terminate were amplified using primer pair P07/P08 and were used to replace the corresponding part of plasmid pHYcas9prsA, yielding plasmids pHYcas9pre and pHYcas9PPI, respectively.

CRISPR/Cas9 gene insertion plasmids pHYcas9pre and pHYcas9PPI were individually transformed into B. subtilis WS9 and transformants were spread onto LB agar containing $20 \mathrm{mg} / \mathrm{l}$ tetracycline. The gene insertion mutants were identified using colony PCR with primer pair P17/P18. The PCR products of the desired transformants appeared about 2,000 bp longer than those of transformants containing the normal strain in a gel electrophoresis analysis. Promising PCR products were characterized using DNA sequencing. Finally, the mutant strains were cultivated at $51^{\circ} \mathrm{C}$ for $10 \mathrm{~h}$ to cure the CRISPR/Cas9 gene insertion plasmids, yielding host strains $B$. subtilis WS9pre and B. subtilis WS9PPI, respectively.

\section{Biomass Assay}

The dry cell weight (DCW) was determined as follows: Cells in a $5 \mathrm{ml}$ sample of CB were pelleted by centrifugation at $13,800 \mathrm{~g}$ and $4^{\circ} \mathrm{C}$ for $5 \mathrm{~min}$. The pellet was resuspended with $0.9 \%(\mathrm{w} / \mathrm{v}) \mathrm{NaCl}$ solution, re-pelleted, and then dried to constant weight at $105^{\circ} \mathrm{C}$.

\section{Bacterial Cell Disruption}

Bacterial cell disruption was performed using ultrasound as follows: Cells in the CB were pelleted by centrifugation at $13,800 \mathrm{~g}$ and $4^{\circ} \mathrm{C}$ for $5 \mathrm{~min}$, and then resuspended in equal volume of deionized water. Lysozyme $(0.9 \mathrm{mg} / \mathrm{ml})$ was added to the suspension and the mixture was incubated at $37^{\circ} \mathrm{C}$ for $30 \mathrm{~min}$. The mixture was then disrupted in an ice water bath using an Ultrasonic Homogenizer (JY92-IIDN, Ningbo Xinzhi Biotechnology Co., Ltd. China), at power setting of 20\%, and pulse mold of working $2 \mathrm{~s}$ and stopping $3 \mathrm{~s}$, for $10 \mathrm{~min}$. The yielded solution was centrifuged at $13,800 \mathrm{~g}$ and $4^{\circ} \mathrm{C}$ for $5 \mathrm{~min}$ to produce an ultrasonic disruption supernatant (UDS) and disruption pellets. The disruption pellets were resuspended with equal volume of deionized water to produce an ultrasonic disruption sediment solution (UDSS).

Alternatively, bacterial cells were disrupted using the Bacterial Protein Extraction Kit (Beijing ComWin Biotech Co., Ltd., China) as follows: Cells in the CB were pelleted by centrifugation at $13,800 \mathrm{~g}$ and $4^{\circ} \mathrm{C}$ for $5 \mathrm{~min}$. The pelleted cells were resuspended in equal volume of bacterial protein extraction reagent, which contained $0.1 \mathrm{mg} / \mathrm{ml}$ of lysozyme and a nonionic detergent. This suspension was incubated at $37^{\circ} \mathrm{C}$ and $200 \mathrm{rpm}$ for $2 \mathrm{~h}$ to disrupt the cells. The yielded solution was centrifuged at $13,800 \mathrm{~g}$ and $4^{\circ} \mathrm{C}$ for 5 min to produce the Bacterial Protein Extraction Kit disruption supernatant (KDS) and disruption pellets. The disruption pellets were resuspended with equal volume of deionized water to produce Bacterial Protein Extraction Kit disruption sediment solution (KDSS).

\section{Heat Treatment}

A certain volume of the $\mathrm{CB}$ was centrifuged at $13,800 \mathrm{~g}$ and $4^{\circ} \mathrm{C}$ for $5 \mathrm{~min}$ to produce culture media (CM) and bacterial cell pellets (Fig. S3). The bacterial cell pellets were resuspended with equal volume of deionized water to 
produce bacterial cell solution (BCS). One milliliter of the $\mathrm{CB}, \mathrm{CM}, \mathrm{BCS}$, UDS, and KDS were heat treated by placing them in a $90^{\circ} \mathrm{C}$ water bath for $15 \mathrm{~min}$. The heat-treated CM, UDS, and KDS were shaken well and then assayed for enzyme activity. The heat-treated $\mathrm{CB}$ and BCS were centrifuged at $13,800 \mathrm{~g}$ and $4^{\circ} \mathrm{C}$ for $5 \mathrm{~min}$. The supernatant was assayed for enzyme activity, and the sediment was resuspended in $1 \mathrm{ml}$ of deionized water, shaken well and assayed for enzyme activity. One milliliter of the UDSS and KDSS was heat treated by placing it in a $90^{\circ} \mathrm{C}$ water bath for $15 \mathrm{~min}$. The resulting mixture was shaken well and assayed for enzyme activity.

\section{Enzyme Activity Assay}

The a-amylase activity was measured by determining the concentration of reducing sugars liberated from soluble starch. The reaction was initiated by adding $0.1 \mathrm{ml}$ of appropriately diluted enzyme solution to a preheated assay mixture containing $1 \mathrm{ml}$ of $1 \%(\mathrm{w} / \mathrm{v})$ soluble starch and $0.9 \mathrm{ml}$ of sodium citrate buffer $(50 \mathrm{mM}, \mathrm{pH}$ 5.0). The assay solution was then incubated at $100^{\circ} \mathrm{C}$ in a boiling water bath for $10 \mathrm{~min}$. The assay was terminated by adding $3 \mathrm{ml}$ of 3,5-dinitrosalicylic acid solution. The resulting mixture was boiled for $7 \mathrm{~min}$, and then immersed in ice water. Finally, the mixture was diluted with $10 \mathrm{ml}$ of deionized water and the absorbance at $540 \mathrm{~nm}$ was measured with a spectrophotometer. One unit of $\alpha$-amylase activity was defined as the amount of enzyme that produced $1 \mu \mathrm{mol}$ of reducing sugar per minute from soluble starch under the condition described above [11].

\section{Protein Analysis}

Protein analysis was conducted by using sodium dodecyl sulfate-polyacrylamide gel electrophoresis (SDSPAGE). Samples were analyzed using a 5\% stacking gel and a 12.5\% separating gel. CB supernatants (20 $\mu$ l) or UDSs $(20 \mu \mathrm{l})$ were mixed with $5 \mu \mathrm{l}$ of SDS-PAGE buffer $(5 x)$ and then placed in a boiling water bath for 5 min. Cell ultrasonic disruption sediments of $1 \mathrm{ml} \mathrm{CB}$ were mixed with $20 \mu \mathrm{l}$ of SDS-PAGE buffer $(5 \times)$, and then placed in a boiling water bath for $5 \mathrm{~min}$. Then, $8 \mu \mathrm{l}$ of supernatant mixtures and $1 \mu \mathrm{l}$ of sediment mixtures were loaded onto the gel for analysis. After electrophoresis, the gels were stained with Coomassie Brilliant Blue R-250 dye. To determine the identity of the protein present in inclusion bodies identified using SDS-PAGE analysis, the corresponding band was excised and analyzed using matrix-assisted laser desorption/ionization-tandem time of flight mass spectrometry (MALDI-TOF/TOF) by Shanghai Haoze Biomedical Technology Co., Ltd. (China).

\section{Statistical Analysis}

All experiments were conducted independently at least three times. The results are presented as the mean \pm SD. Statistical analyses were conducted using Student's $t$ test, and differences resulting in values of $p<0.05$ were considered statistically significant.

\section{Results}

\section{Soluble P. furiosus a-Amylase Production Is Increased by Co-Expression with Molecular Chaperones}

In our previous study, substantial amounts of inclusion bodies were formed in the cytoplasm of $B$. subtilis WS9amy, the $P$. furiosus $\alpha$-amylase-producing strain, which was constructed through transforming expression plasmid pHY300PLK/pfa into host strain B. subtilis WS9. An SDS-PAGE analysis of these inclusion bodies contained two bands (Fig. 2A). MALDI-TOF/TOF analysis of the material in these bands (Figs. S4 and S5) showed that both contained $P$. furiosus $\alpha$-amylase, suggesting that $P$. furiosus $\alpha$-amylase was present as both a monomer and a homodimer in the SDS-PAGE analysis. The relative smaller size of monomer and homodimer than the theoretical size of about 50 and $100 \mathrm{kDa}$ may be related to their partially folded structure under the SDS-PAGE analysis, owing to their excellent thermostability. Similar results have been obtained in previous studies [11,28].

Initial efforts to reduce inclusion body formation during P. furiosus $\alpha$-amylase production in $B$. subtilis WS9 involved co-expression of $P$. furiosus $\alpha$-amylase with molecular chaperones from thermophilic archaea (Fig. 1A) $[22,26]$. M. jannaschii prefoldins and P. furiosus PPIase were the molecular chaperones chosen for co-expression studies. Expression of the genes encoding M. jannaschii prefoldins and P. furiosus PPIase was driven by the $B$. amyloliquefaciens xylose-inducible promoter $\mathrm{P}_{x y l}$. Co-expression cassettes were individually inserted into the $a m y E$ locus of the B. subtilis WS9 genome by using the CRISPR/Cas9 system with gene insertion plasmids pHYcas9pre and pHYcas9PPI (Fig. S2B). This process yielded B. subtilis WS9pre, which expresses M. jannaschii prefoldins, and $B$. subtilis WS9PPI, which expresses $P$. furiosus PPIase. The $P$. furiosus a-amylase expression plasmid pHY300PLK/pfa was transformed into B. subtilis WS9pre and B. subtilis WS9PPI, yielding B. subtilis WS9preamy and B. subtilis WS9PPIamy, respectively. The control strain, B. subtilis WS9amy, was the parent strain harboring $\mathrm{pHY} 300 \mathrm{PLK} / p f a$.

The levels of a-amylase produced by B. subtilis WS9amy, B. subtilis WS9preamy and B. subtilis WS9PPIamy were assessed in shake-flask culture by incubating for $60 \mathrm{~h}$ with different concentrations $(0 \%, 0.25 \%, 0.5 \%, 1 \%$, and $2 \%)$ of xylose. In the absence of added xylose, the extracellular a-amylase activities of B. subtilis WS9amy, B. subtilis WS9preamy and B. subtilis WS9PPIamy were 135.1, 145.5, and $156.7 \mathrm{U} / \mathrm{ml}$, respectively (Figs. 2B-2D). B. subtilis WS9amy produced the highest $a$-amylase activity $(161.8 \mathrm{U} / \mathrm{ml})$ with $0.5 \%$ xylose, $B$. subtilis WS9preamy produced the highest $\alpha$-amylase activity $(149.4 \mathrm{U} / \mathrm{ml})$ with $0.25 \%$ xylose, and $B$. subtilis WS9PPIamy showed the highest $\alpha$ amylase activity without added xylose. It has been reported that promoter $\mathrm{P}_{x y l}$ has weak transcription activity, even in the absence of xylose [35]. Therefore, there must be sufficient basal PPIase expression in B. subtilis WS9PPIamy to assist $\alpha$-amylase in an unfolded export-competent state, and increased PPIase expression had a negative effect on $\alpha$-amylase production. Since the $\alpha$-amylase activity produced by $B$. subtilis WS9PPIamy in the absence of added xylose was 1.2-fold greater than that produced by B. subtilis WS9amy under the same conditions, and the 


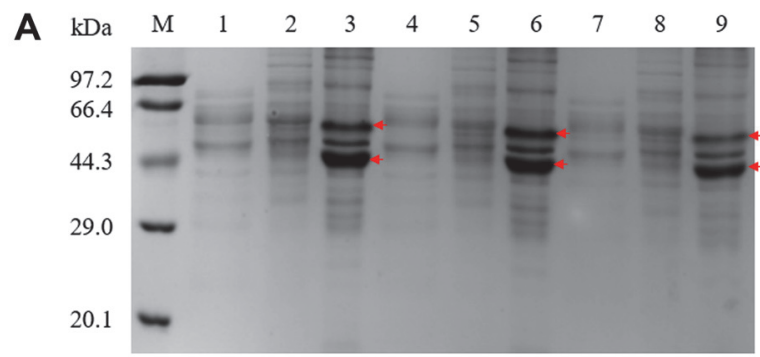

B

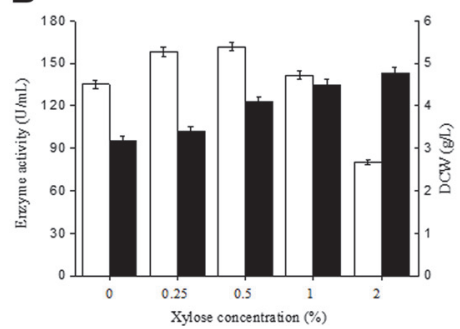

C

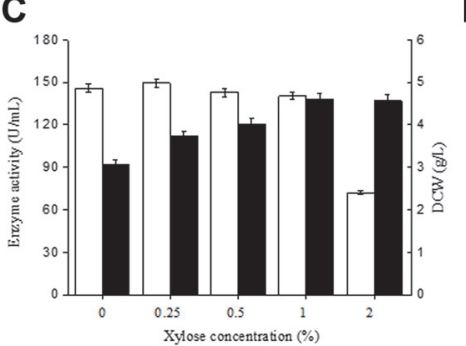

D

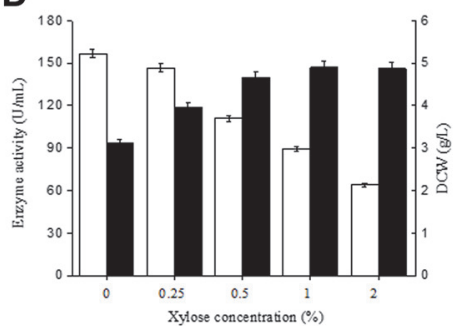

Fig. 2. P. furiosus $\boldsymbol{\alpha}$-amylase production in B. subtilis strains. (A) SDS-PAGE analysis of a-amylase production in B. subtilis WS9amy, B. subtilis WS9preamy and B. subtilis WS9PPIamy. M, protein molecular weight marker; 1 , supernatant of CB (B. subtilis WS9amy); 2, UDS (B. subtilis WS9amy); 3, sediment of cell ultrasonic disruption (B. subtilis WS9amy); 4 , supernatant of CB (B. subtilis WS9preamy); 5, UDS (B. subtilis WS9preamy); 6, sediment of cell ultrasonic disruption (B. subtilis WS9preamy); 7, supernatant of CB (B. subtilis WS9PPIamy); 8, UDS (B. subtilis WS9PPIamy); 9, sediment of cell ultrasonic disruption (B. subtilis WS9PPIamy). The bands corresponding to a-amylase inclusion bodies are marked with arrows. (B-D) P. furiosus $\alpha$-amylase production in B. subtilis WS9amy (B), B. subtilis WS9preamy (C) and B. subtilis WS9PPIamy (D) using different xylose concentrations. For all panels: white bar, enzyme activity; black bar, DCW.

addition of xylose increases the complexity and cost of fermentation, use of B. subtilis WS9PPIamy in the absence of xylose seems the best choice for the industrial production of $P$. furiosus $\alpha$-amylase.

Heat Treatment Increases the Production of Soluble, Active P. furiosus a-Amylase

During shake-flask cultivations of $B$. subtilis WS9PPIamy, the extracellular activity increased with fermentation time, reaching $1,141.1 \mathrm{U} / \mathrm{ml}$ at $310 \mathrm{~h}$ (Fig. 3A). Considering that native $P$. furiosus $\alpha$-amylase is produced within a hyperthermophilic environment $\left(\sim 100^{\circ} \mathrm{C}\right)$ and possesses a high level of molecular rigidity, and that its denaturation requires considerable energy $(316 \mathrm{~kJ} / \mathrm{mol})$, the correct folding of $P$. furiosus $\alpha$-amylase may need a high level of energy. Heat treatment can provide energy in a physical way. Meanwhile, the high thermostability of $P$. furiosus $\alpha$-amylase protects it from thermal deactivation. It seemed reasonable to investigate whether heat treatment can increase the yield of soluble, active P. furiosus $\alpha$-amylase through the transfer of kinetic energy (Fig. 1B).

To test this hypothesis, shake-flask cultivations that had been incubated at $33^{\circ} \mathrm{C}$ for $60,72,96$, and $120 \mathrm{~h}$ were incubated at $90^{\circ} \mathrm{C}$ for $30 \mathrm{~min}$, and then the $\mathrm{CB}$ supernatants were assayed for $\alpha$-amylase activity. As shown in Table 3, the enzyme activity increased 2.6- to 7.2-fold after heat treatment, yielding a highest extracellular activity of $1,710.8 \mathrm{U} / \mathrm{ml}$ ( $120 \mathrm{~h}$ sample). Indeed, the extracellular activity in the original samples increased substantially from 60 to $120 \mathrm{~h}$, while the activities of the heat-treated samples did not show a correspondingly large increase, especially from 72 to $120 \mathrm{~h}$. The reason for this may be that a substantial portion of the enzyme produced in the first $72 \mathrm{~h}$ formed inclusion bodies that slowly unfolded to the export-competent state and was secreted into the CM (Fig. 3B). Heat treatment may accelerate soluble active extracellular production of the hyperthermophilic enzyme by providing kinetic energy.

To determine the optimal heat treatment conditions, shake-flask CBs of B. subtilis WS9PPIamy incubated at $33^{\circ} \mathrm{C}$ for $72 \mathrm{~h}$ were incubated at $80^{\circ} \mathrm{C}, 90^{\circ} \mathrm{C}$, or $100^{\circ} \mathrm{C}$ for $0,5,15,30,60$, or $90 \mathrm{~min}$, and then the heat-treated $\mathrm{CB}$ supernatants were assayed for $\alpha$-amylase activity. As show in Table 4 , the temperature of the heat treatment did not have a significant effect. Similarly, the enzyme activity present in the CB supernatant did not significantly increase

Table 3. Effects of culture time and heat treatment on extracellular a-amylase activity of $B$. subtilis WS9PPIamy.

\begin{tabular}{ccc}
\hline Time $(\mathrm{h})$ & Enzyme activity $(\mathrm{U} / \mathrm{ml})$ & Heat-treated enzyme activity $(\mathrm{U} / \mathrm{ml})$ \\
\hline 60 & $156.7 \pm 3.1$ & $1,135.0 \pm 25.5$ \\
72 & $233.3 \pm 6.6$ & $1,588.3 \pm 30.7$ \\
96 & $484.1 \pm 8.9$ & $1,690.8 \pm 29.6$ \\
120 & $673.2 \pm 19.9$ & $1,710.8 \pm 47.7$ \\
\hline
\end{tabular}



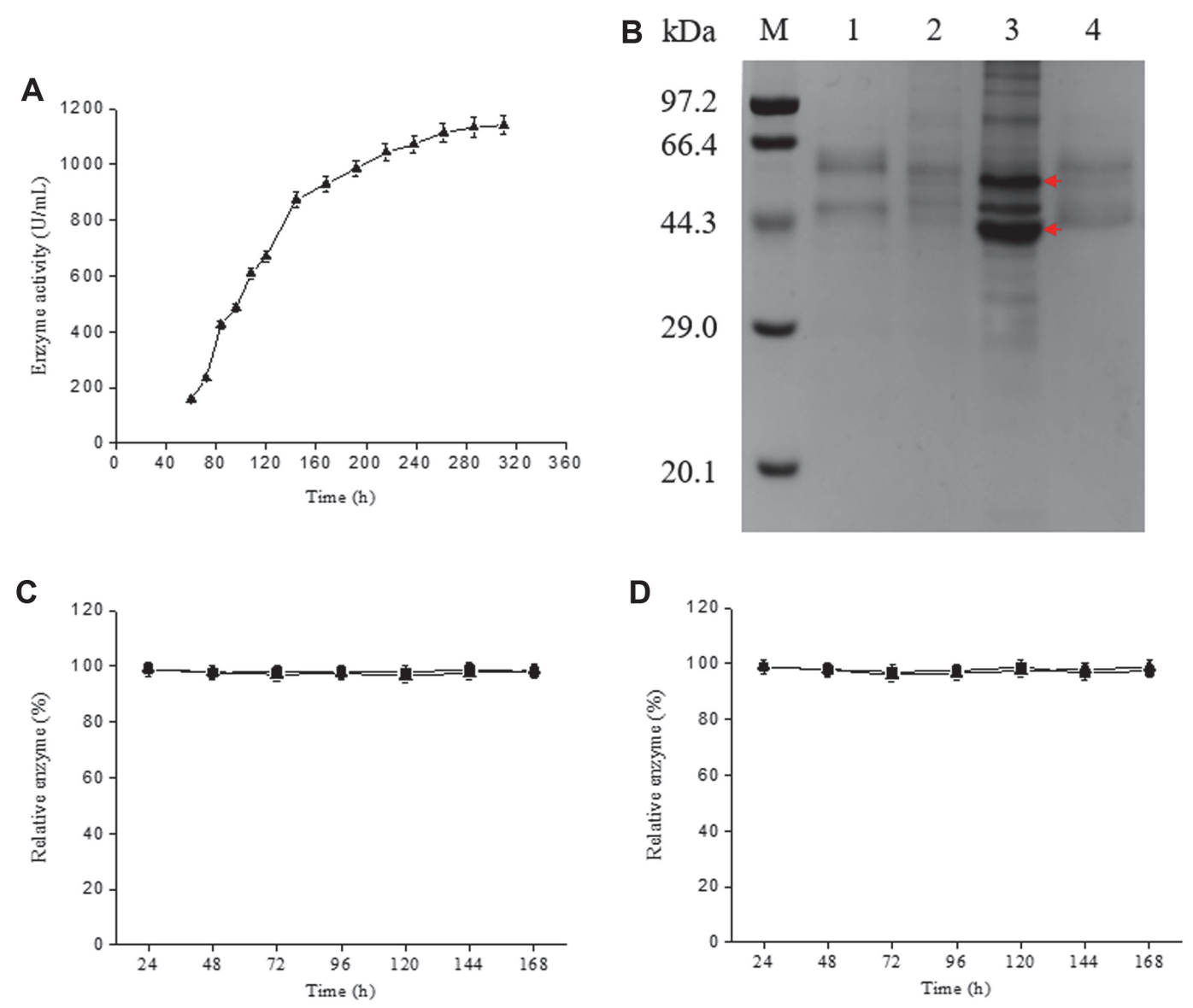

Fig. 3. P. furiosus $\alpha$-amylase production and stability. (A) $\alpha$-Amylase production by B. subtilis WS9PPIamy over an extended fermentation period. (B) SDS-PAGE analysis of a-amylase production in B. subtilis WS9PPlamy after shake-flask cultivation for $72 \mathrm{~h}$ and heat-treated sample. $\mathrm{M}$, protein molecular weight marker; 1 , supernatant of CB; 2 , UDS; 3 , sediment of cell ultrasonic disruption; 4, supernatant of heat-treated CB. The bands corresponding to $\alpha$-amylase inclusion bodies are marked with arrows. (C) The stability of untreated extracellular $\alpha$-amylase at $4^{\circ} \mathrm{C}(\boldsymbol{\square})$ and $25^{\circ} \mathrm{C}(\boldsymbol{\Delta})$. (D) The stability of heattreated $\alpha$-amylase at $4^{\circ} \mathrm{C}(\boldsymbol{\square})$ and $25^{\circ} \mathrm{C}(\boldsymbol{\Delta})$.

Table 4. Effects of temperature and heat treatment time on extracellular $\alpha$-amylase activity (U/ml) of B. subtilis WS9PPIamy.

\begin{tabular}{ccccccc}
\hline \multirow{2}{*}{$\begin{array}{c}\text { Temp. } \\
\left({ }^{\circ} \mathrm{C}\right)\end{array}$} & 0 & 5 & 15 & 30 & 60 & 90 \\
\cline { 2 - 7 } & $233.3 \pm 6.6$ & $843.3 \pm 20.5$ & $1,409.0 \pm 32.9$ & $1,468.1 \pm 27.9$ & $1,535.4 \pm 33.2$ & $1,578.9 \pm 39.1$ \\
100 & $233.3 \pm 6.6$ & $871.8 \pm 14.3$ & $1,456.7 \pm 25.4$ & $1,588.3 \pm 30.7$ & $1,605.8 \pm 48.1$ & $1,591.3 \pm 43.2$ \\
90 & $233.3 \pm 6.6$ & $840.8 \pm 23.5$ & $1,404.8 \pm 22.9$ & $1,443.2 \pm 34.1$ & $1,562.3 \pm 42.4$ & $1,607.9 \pm 30.1$ \\
80 & & & &
\end{tabular}

when the duration of the heat treatment exceeded $15 \mathrm{~min}$. Therefore, $90^{\circ} \mathrm{C}$ for $15 \mathrm{~min}$ was selected as the optimal conditions for heat treatment. Under these conditions, the enzyme activity present in the CB supernatant was 6.2fold greater than that observed in the absence of heat treatment (Fig. 3B).

\section{Effect of Heat Treatment on $\alpha$-Amylase Activity in Different Fractions}

Shake-flask CBs of WS9PPIamy incubated at $33^{\circ} \mathrm{C}$ for $72 \mathrm{~h}$ were fractionated to determine the amount of $\alpha$ amylase activity in each fraction and the effect of heat treatment on each (Fig. S3). The results are shown in Table 5. The $\alpha$-amylase activity of the CB sampled prior to any heat treatment was $393.5 \mathrm{U} / \mathrm{ml}$. Pelleting the cells of CB by centrifugation produced a CM with an a-amylase activity of $233.3 \mathrm{U} / \mathrm{ml}$, and resuspending the cell pellet with equal volume of deionized water yielded a BCS with an $\alpha$-amylase activity of $149.7 \mathrm{U} / \mathrm{ml}$. Ultrasonic disruption of the BCS, followed by centrifugation, produced a UDS with an $\alpha$-amylase activity of $124.3 \mathrm{U} / \mathrm{ml}$ and a UDSS with an $\alpha$-amylase activity of $377.5 \mathrm{U} / \mathrm{ml}$. These different fractions were heat treated at $90^{\circ} \mathrm{C}$ for 15 min separately. When the original $\mathrm{CB}$ was sampled after heat treatment, and then centrifuged to produce a heat-treated 
Table 5. Effects of heat treatment on the different fractions of B. subtilis WS9PPIamy.

\begin{tabular}{ccc}
\hline Fractions & Enzyme activity $(\mathrm{U} / \mathrm{ml})$ & Heat-treated enzyme activity $(\mathrm{U} / \mathrm{ml})$ \\
\hline CB & $393.5 \pm 7.3$ & $1,456.7 \pm 25.4^{\mathrm{a}}$ and $438.6 \pm 10.4^{\mathrm{b}}$ \\
CM & $233.3 \pm 6.6$ & $292.4 \pm 4.1$ \\
BCS & $149.7 \pm 4.5$ & $1,102.6 \pm 13.5^{\mathrm{c}}$ and $204.1 \pm 4.8^{\mathrm{d}}$ \\
UDS & $124.3 \pm 3.0$ & $87.9 \pm 2.2$ \\
UDSS & $377.5 \pm 5.4$ & $273.9 \pm 4.4$ \\
KDS & $145.6 \pm 3.2$ & $148.3 \pm 3.0$ \\
KDSS & $357.8 \pm 6.1$ & $515.8 \pm 14.0$ \\
\hline
\end{tabular}

${ }^{a}$ The enzyme activity of heat-treated CB supernatant; ${ }^{b}$ the enzyme activity of heat-treated CB sediment solution that was resuspended with equal volume of deionized water; ${ }^{c}$ the enzyme activity of heat-treated BCS supernatant; ${ }^{\mathrm{d}}$ the enzyme activity of heat-treated BCS sediment solution that was resuspended with equal volume of deionized water; $\mathrm{CB}$, culture broth; $\mathrm{CM}$, culture medium; BCS, bacterial cell solution; UDS, ultrasonic disruption supernatant; UDSS, ultrasonic disruption sediment solution; KDS, Bacterial Protein Extraction Kit disruption supernatant; KDSS, Bacterial Protein Extraction Kit disruption sediment solution.

supernatant and a heat-treated sediment solution, the enzyme activities of the supernatant and sediment solution were $1,456.7$ and $438.6 \mathrm{U} / \mathrm{ml}$, respectively. The enzyme activity of heat-treated CM was $292.4 \mathrm{U} / \mathrm{ml}$. When the BCS was heat-treated and centrifuged to produce a heat-treated supernatant and a heat-treated sediment solution, the enzyme activities of the supernatant and sediment solution were $1,102.6$ and $204.1 \mathrm{U} / \mathrm{ml}$, respectively. The enzyme activities of heat-treated UDS and UDSS were $87.9 \mathrm{U} / \mathrm{ml}$ and $273.9 \mathrm{U} / \mathrm{ml}$, respectively.

For the sake of comparison, the $\alpha$-amylase activity of heat-treated BCS supernatant $(1,102.6 \mathrm{U} / \mathrm{ml})$ was $75.7 \%$ of the $\alpha$-amylase activity of heat-treated CB supernatant $(1,456.7 \mathrm{U} / \mathrm{ml})$, while the $\alpha$-amylase activity of heat-treated CM $(292.4 \mathrm{U} / \mathrm{ml})$ was $20.1 \%$ of the $\alpha$-amylase activity of heat-treated CB supernatant $(1,456.7 \mathrm{U} / \mathrm{ml})$. These results are consistent with the hypothesis that heat treatment might accelerates the unfolding and export of a partintracellular $P$. furiosus $a$-amylase that would otherwise be or remain deposited in inclusion bodies. Furthermore, the sum of $\alpha$-amylase activities in heat-treated CB supernatant and sediment solution is $1,895.3 \mathrm{U} / \mathrm{ml}$, which is similar with the sum of $\alpha$-amylase activities in heat-treated CM, heat-treated BCS supernatant, and sediment solution $(1,599.1 \mathrm{U} / \mathrm{ml})$, while is much higher than the sum of $\alpha$-amylase activities in heat-treated CM, UDS and UDSS $(654.2 \mathrm{U} / \mathrm{ml})$. These results strongly suggest that whole bacteria must be present for heat treatment to significantly augment $\alpha$-amylase activity. An alternative explanation, that ultrasonic disruption was too harsh and prevented the heat activation of cellular components, was tested by disrupting the cells using the Bacterial Protein Extraction Kit, which performs a more mild disruption using lysozyme and nonionic detergent. Under these conditions, the $\alpha$-amylase activities of the KDS and KDSS were 145.6 and $357.8 \mathrm{U} / \mathrm{ml}$, respectively. These results are quite similar to those obtained using ultrasonic disruption. After heat treatment, the enzyme activities of the KDS $(148.3 \mathrm{U} / \mathrm{ml})$ was similar with before, while the enzyme activities of the KDSS increased from 357.8 to $515.8 \mathrm{U} / \mathrm{ml}$. Although the total activity of heat-treated CM, KDS and KDS $(956.5 \mathrm{U} / \mathrm{ml})$ is still much lower than the activity obtained by heat treating the intact $\mathrm{CB}$, it is $46.2 \%$ higher than that of the ultrasonic disruption $(654.2 \mathrm{U} / \mathrm{ml})$. These results are partly consistent with the above speculation that ultrasonic disruption was too harsh and prevented the heat activation of cellular components.

\section{Stability of Heat-Treated Enzyme During Storage}

The $\alpha$-amylase in the supernatant of heat-treated $\mathrm{CB}$ was stored at $4^{\circ} \mathrm{C}$ or $25^{\circ} \mathrm{C}$ and samples were assayed at regular intervals, during which the untreated extracellular $\alpha$-amylase was assayed as control. As shown in Figs. 3C, $3 \mathrm{D}$, the heat-treated enzyme remained essentially $100 \%$ active over a 168 -h period ( 1 week), similarly with that of untreated enzyme. This extraordinary stability may reflect that the heat-treated enzyme is properly folded just like a normally secreted enzyme.

\section{Optimization of Shake-Flask Fermentation}

To further improve P. furiosus a-amylase production by B. subtilis WS9PPIamy, the culture conditions were optimized in shake-flask experiments with a fixed fermentation time of $60 \mathrm{~h}$, during which the extracellular $\alpha$ amylase activities were measured (Fig. 1C). In initial experiments, the yeast extract and peptone present in TB medium were replaced with $36 \mathrm{~g} / \mathrm{l}$ concentrations of seventeen different nitrogen sources including yeast extract powder, industrial yeast extract powder, yeast extract fermentation, fish meal peptone, soy peptone, bone peptone, peptone 1 , industrial peptone, tryptone, beef peptone, beef meal, beef extract fermentation, corn steep powder, cottonseed meal, soy meal 1 , and soy meal 2 . The greatest $\alpha$-amylase activities were obtained with tryptone $(143.1 \mathrm{U} / \mathrm{ml})$, beef extract fermentation $(136.6 \mathrm{U} / \mathrm{ml})$, beef peptone $(125.4 \mathrm{U} / \mathrm{ml})$, yeast extract powder $(99.8 \mathrm{U} / \mathrm{ml})$, and beef meal $(95.9 \mathrm{U} / \mathrm{ml})$. The nitrogen sources yielding the greatest cell mass at $60 \mathrm{~h}$ were corn steep powder, industrial peptone and soy peptone, which gave DCW values of 5.4, 4.6, and 4.2 g/l, respectively (Fig. 4A). When both price and enzyme activity yield were taken into consideration, a combination of yeast extract and soy peptone was selected for use in subsequent experiments. The concentrations of soy peptone and yeast extract powder were optimized by keeping their total concentration between 21 and $33 \mathrm{~g} / \mathrm{l}$. The highest enzyme activity, $136.8 \mathrm{U} / \mathrm{ml}$, was obtained with $15 \mathrm{~g} / \mathrm{l}$ soy peptone and $12 \mathrm{~g} / \mathrm{l}$ yeast extract powder. The next highest enzyme activity, $130.8 \mathrm{U} / \mathrm{ml}$, was obtained with $18 \mathrm{~g} / \mathrm{l}$ soy peptone and $9 \mathrm{~g} / \mathrm{l}$ yeast extract powder. The cell masses obtained under these conditions were 2.2 and $2.4 \mathrm{~g} / \mathrm{l}$, respectively (Fig. 4B). Considering the higher price of yeast extract powder 
A

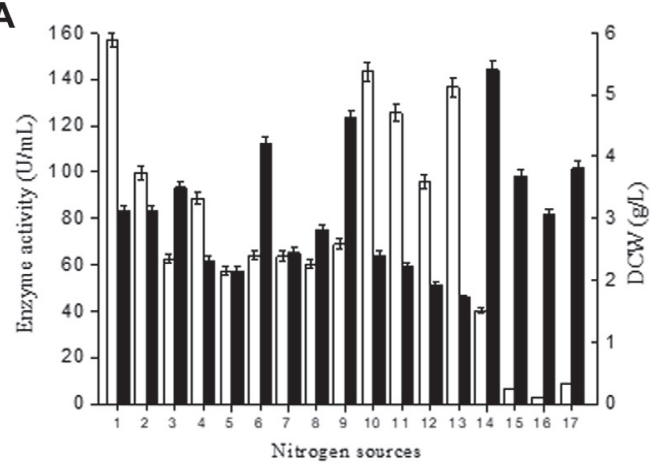

$\mathbf{C}$

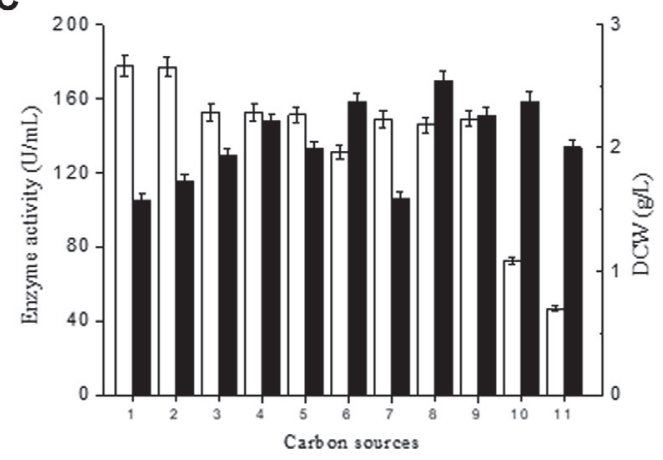

B

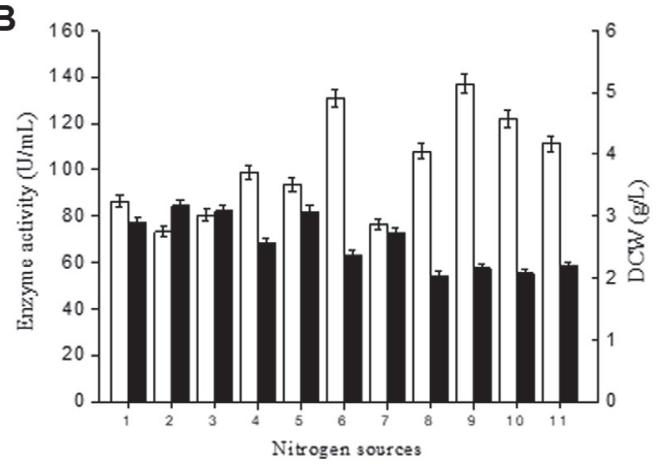

D

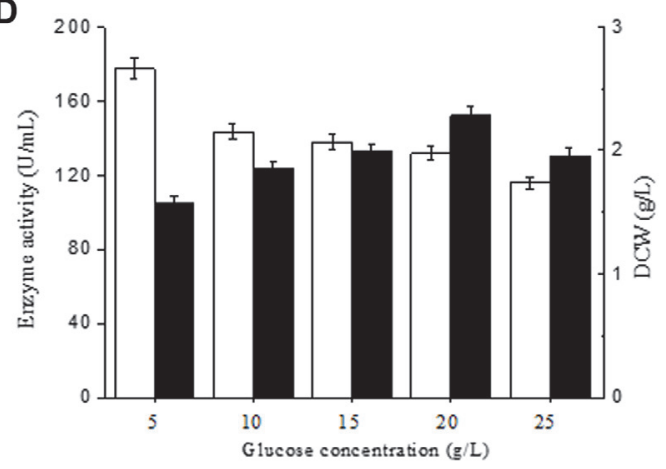

Fig. 4. Optimization of the nitrogen and carbon sources in the growth medium. (A) The effects of different of nitrogen sources. 1, TB; 2, yeast extract powder; 3 , industrial yeast extract powder; 4 , yeast extract fermentation; 5 , fish meal peptone; 6 , soy peptone; 7 , bone peptone; 8 , peptone $1 ; 9$, industrial peptone; 10 , tryptone; 11 , beef peptone; 12 , beef meal; 13 , beef extract fermentation; 14, corn steep powder; 15, cottonseed meal; 16, soy meal 1; 17, soy meal 2. (B) Effect of varying the of soy peptone to yeast extract powder concentration (g/l) ratio. 1,21 and $12 ; 2,21$ and $9 ; 3,21$ and $6 ; 4,18$ and 15;5, 18 and 12;6, 18 and $9 ; 7,18$ and $6 ; 8,18$ and 3;9,15 and 12;10,15 and 9;11,15 and 6. (C) The effects of different of carbon sources. 1, glucose; 2, fructose; 3 , maltose; 4 , maltodextrin; 5 , lactose; 6 , glycerol; 7 , xylose; 8 , sucrose; 9 , potato starch; 10 , soluble starch; 11 , waxy corn starch. (D) Effect of varying the glucose concentration. For all panels: white bar, enzyme activity; black bar, DCW.

than soy peptone, $18 \mathrm{~g} / \mathrm{l}$ soy peptone and $9 \mathrm{~g} / \mathrm{l}$ yeast extract powder were used as the complex nitrogen source in subsequent optimization experiments.

Eleven different carbon sources were evaluated at a concentration of $5 \mathrm{~g} / \mathrm{l}$, including glucose, fructose, maltose, maltodextrin, lactose, glycerol, xylose, sucrose, potato starch, soluble starch and waxy corn starch. Use of glucose yielded the highest enzyme activity, $177.3 \mathrm{U} / \mathrm{ml}$, and a DCW of $1.6 \mathrm{~g} / \mathrm{l}$ (Fig. 4C). After selecting glucose as the optimal carbon source, its concentration was optimized using experiments containing 5, 10, 15, 20, and $25 \mathrm{~g} / \mathrm{l}$ glucose. The highest $\alpha$-amylase activity was obtained with a glucose concentration of $5 \mathrm{~g} / \mathrm{l}$ (Fig. 4D). Thus, the medium employed in subsequent optimization experiments included $5 \mathrm{~g} / \mathrm{l}$ glucose.

To assess the effect of metal ions on $\alpha$-amylase production cell growth, $1 \mathrm{mM}$ concentrations of $\mathrm{Fe}^{3+}, \mathrm{Fe}^{2+}, \mathrm{Mn}^{2+}$, $\mathrm{Mg}^{2+}, \mathrm{Ca}^{2+}, \mathrm{Co}^{2+}, \mathrm{Cu}^{2+}, \mathrm{Al}^{3+}, \mathrm{Ba}^{2+}$, and $\mathrm{Zn}^{2+}$ were added, separately, to the medium. The results are presented in Fig. 5A. The highest $\alpha$-amylase activity, $204.9 \mathrm{U} / \mathrm{ml}$, was obtained in the presence of $\mathrm{Al}^{3+}$. The DCW under these conditions was $2.2 \mathrm{~g} / \mathrm{l}$. The optimal $\mathrm{Al}^{3+}$ concentration was investigated by adding $0.2,0.5,1,3,6$, and $10 \mathrm{mmol} / 1$ $\mathrm{Al}^{3+}$. The highest $\alpha$-amylase activity, $230.0 \mathrm{U} / \mathrm{ml}$, was obtained with $3 \mathrm{mmol} / \mathrm{l} \mathrm{Al}{ }^{3+}$, which yielded a DCW of $1.9 \mathrm{~g} /$ 1 (Fig. 5B). The medium used in subsequent optimization experiments contained $3 \mathrm{mmol} / \mathrm{l} \mathrm{Al} \mathrm{l}^{3+}$.

The fermentation temperature was assessed using cultures at $30,33,37,42$, and $47^{\circ} \mathrm{C}$. The highest a-amylase activity of $230.0 \mathrm{U} / \mathrm{ml}$ was obtained from cultures incubated at $33^{\circ} \mathrm{C}$, which yielded a DCW of $1.9 \mathrm{~g} / \mathrm{l}$ (Fig. $5 \mathrm{C}$ ). Subsequent experiments were conducted at this temperature. The initial $\mathrm{pH}$ of the medium was assessed using media at $\mathrm{pH} 6.0,6.5,7.0,7.5$, and 8.0. The highest $\alpha$-amylase activity, $282.6 \mathrm{U} / \mathrm{ml}$, was obtained at $\mathrm{pH} 7.5$. At this $\mathrm{pH}$, a DCW of $1.2 \mathrm{~g} / \mathrm{l}$ was obtained (Fig. 5D). At pH 7.0, the $\alpha$-amylase activity was $259.4 \mathrm{U} / \mathrm{ml}$ (91.8\% of that obtained at $\mathrm{pH} 7.5$ ) and the DCW was $1.9 \mathrm{~g} / \mathrm{l}$ (158.3\% of that obtained at $\mathrm{pH} 7.5)$. These results show that use of $\mathrm{pH}$ 7.0 would yield better high-density fermentation results than $\mathrm{pH} 7.5$.

Based on these experiments, scale-up fermentation was designed to include a fermentation medium containing soy peptone $(18 \mathrm{~g} / \mathrm{l})$ and yeast extract powder $(9 \mathrm{~g} / \mathrm{l})$ as its complex nitrogen source, glucose $(5 \mathrm{~g} / \mathrm{l})$ as its carbon source, and $\mathrm{Al}^{3+}(3 \mathrm{mmol} / \mathrm{l})$. Fermentation would be conducted at $33^{\circ} \mathrm{C}$ and $\mathrm{pH}$ 7.0.

\section{3-L Fermenter Cultivation}

Producing $P$. furiosus $\alpha$-amylase in a 3 - $\mathrm{L}$ fermenter was envisioned as an initial fermentation stage (ca. $7 \mathrm{~h}$ ) followed by a second phase in which the culture was sustained using a feeding solution. Both phases were 
A

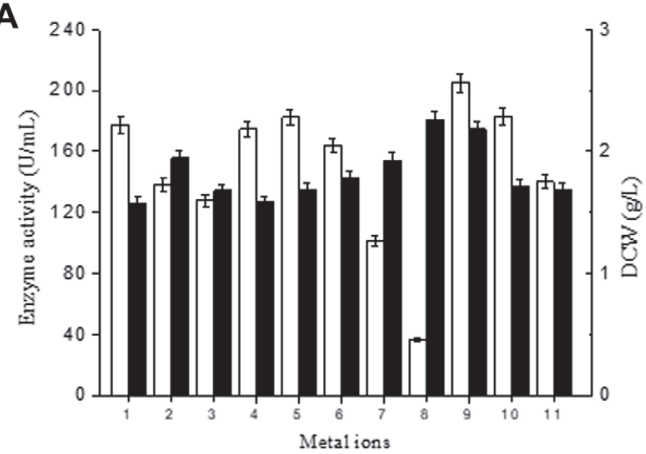

C

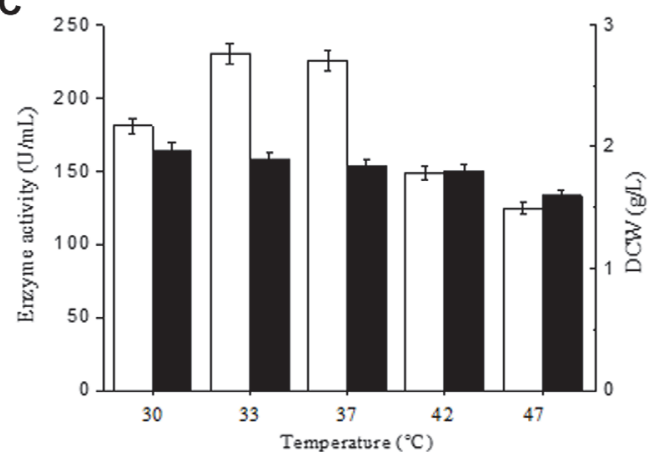

B

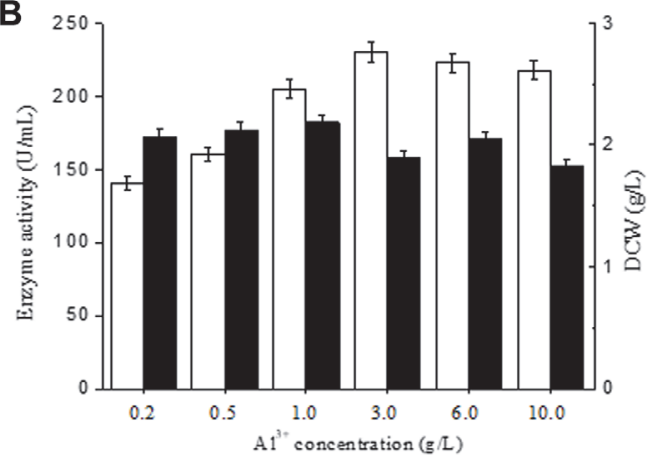

D

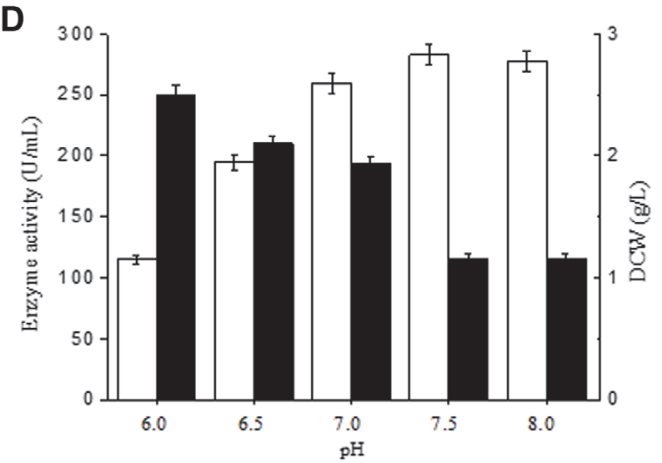

Fig. 5. The effects of added metal ions, $\mathrm{pH}$ and temperature on $P$. furiosus $\alpha$-amylase production. (A) The effects of different metal ions added at $1 \mathrm{mmol} / \mathrm{L}$ concentration. 1 , control; $2, \mathrm{Fe}^{3+} ; 3, \mathrm{Fe}^{2+} ; 4, \mathrm{Mn}^{2+} ; 5, \mathrm{Mg}^{2+} ; 6, \mathrm{Ca}^{2+} ; 7, \mathrm{Co}^{2+} ; 8$, $\mathrm{Cu}^{2+} ; 9, \mathrm{Al}^{3+} ; 10, \mathrm{Ba}^{2+} ; 11, \mathrm{Zn}^{2+}$. (B) Effect of varying the $\mathrm{Al}^{3+}$ concentration. (C) The effect of varying the temperature. (D) The effect of varying the $\mathrm{pH}$. For all panels: white bar, enzyme activity; black bar, DCW.

conducted at $\mathrm{pH} 7.0$ and $33^{\circ} \mathrm{C}$. The initial medium was that described in the previous section. The feeding contained soy peptone and yeast extract powder in a 2:1 (w/w) ratio with a total concentration of $100 \mathrm{~g} / \mathrm{l}$. The feeding solution also contained $500 \mathrm{~g} / \mathrm{l}$ glucose. During the cultivation process, the glucose concentration was measured through a biosensor and controlled below $0.5 \mathrm{~g} / \mathrm{l}$. Beginning at $60 \mathrm{~h}$ of culture, samples were assayed for $a$-amylase before and after heat treatment. The results are presented in Fig. 6 . The cells grew rapidly during the first $45 \mathrm{~h}$ and reached their highest density $(\mathrm{DCW}=36.6 \mathrm{~g} / \mathrm{l})$ at $75 \mathrm{~h}$. Extracellular $\alpha$-amylase activity before heat treatment increased slowly with time and peaked $(1,155.1 \mathrm{U} / \mathrm{ml})$ at $143 \mathrm{~h}$. The extracellular $\alpha$-amylase activity in heat-treated samples rose more sharply and peaked $(3,806.7 \mathrm{U} / \mathrm{ml})$ at $119 \mathrm{~h}$.

In 3-L fermenter cultivation, the appearance of peak heat-treated activity before that of untreated activity was similar to the results seen with shake-flask cultures, supporting our model that P. furiosus $\alpha$-amylase export from the cell in an unfolded export-competent state is a slow process that normally leads to inclusion body formation. However, heat treatment adds kinetic energy that might accelerates the process in both shake-flask and 3-L fermenter, causing a part of the $\alpha$-amylase that would have been lost to inclusion body formation or proteolysis to be exported into the CM as active, properly folded enzyme.

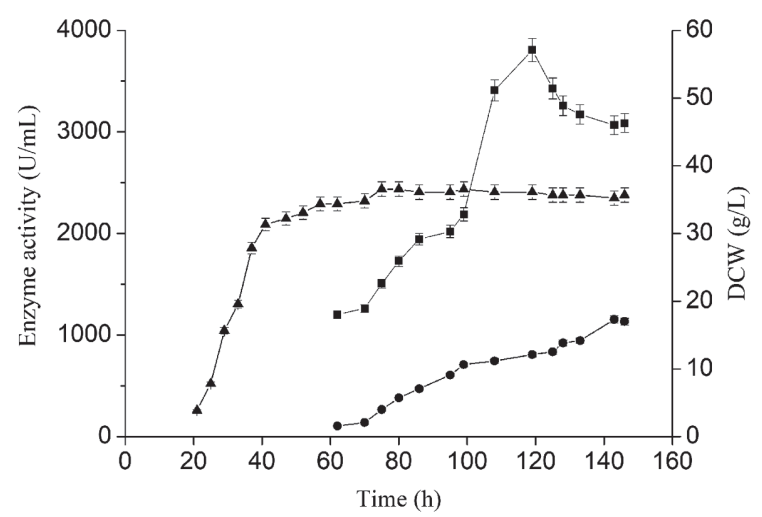

Fig. 6. $P$. furiosus a-amylase production in a 3-L fermenter. $O$, extracellular $a$-amylase activity prior to heat treatment; $\boldsymbol{\square}$, extracellular $\alpha$-amylase activity after heat treatment; $\boldsymbol{\Delta}$, DCW. 


\section{Discussion}

B. subtilis has its own powerful secretory ability for its single membrane structure. In order to control the quality of secreted recombinant proteins, B. subtilis uses its own quality control proteases $\mathrm{HtrA} / \mathrm{HtrB}$, which can degrade unfolded and misfolded proteins in the interface of membrane and cell wall [14]. The expression level of proteases $\mathrm{Htr} \mathrm{A} / \mathrm{HtrB}$ will increase greatly when the recombinant proteins are over-secreted and accumulate in unfolded or misfolded forms, through regulation by the CssR/CssS two-component system [36]. Therefore, secretory proteins quickly fold into the correct structure and use a signal peptide with proper secretory efficiency to avoid stimulation of the CssR/CssS system and causing major degradation [37]. In our previous study (unpublished), after optimizing the signal peptide and overexpression of extracellular chaperone PrsA, the extracellular activity of $P$. furiosus a-amylase increased from 18.3 to $135.1 \mathrm{U} / \mathrm{ml}$, and SDS-PAGE analysis showed that substantial amounts of inclusion bodies formed in the cytoplasm, which was similar with that in E. coli [28]. The formation of inclusion bodies in the cytoplasm avoids extracytoplasmic degradation, while it may also hinder the general translocation process that requires the synthesized proteins in an unfolded export-competent state before translocation [38].

In this study, three strategies of thermophilic archaeal chaperone co-expression, heat treatment and fermentation optimization were applied to improve the soluble production of $P$. furiosus a-amylase in $B$. subtilis (Fig. 1). The co-expression of $P$. furiosus PPIase increased extracellular $P$. furiosus $\alpha$-amylase activity 1.2 -fold in the absence of added xylose. PPIase catalyzes the cis-trans isomerization of prolyl imide bonds in protein, and is a heterologous analogue of B. subtilis chaperone PrsA [23]. Our previous study showed that overexpression of PrsA improved $P$. furiosus $\alpha$-amylase activity 1.13 -fold, which is relatively consistent with the results in this study. Meanwhile, there are some differences between B. subtilis chaperone PrsA and P. furiosus PPIase. B. subtilis chaperone PrsA is mainly located on the outer surface of the cytoplasmic membrane through N-terminal lipomodification, and its chaperone activity was shown to be mainly dependent on the NC domains that form a hydrophobic bowl-like crevice, and are partly dependent on the PPIase domain. P. furiosus PPIase does not have its own signal peptide and was speculated to be an intracellular protein, which may promote intracellular synthesized $P$. furiosus a-amylase to stay in an unfolded export-competent state. The co-expression of M. jannaschii prefoldins increased extracellular $P$. furiosus $\alpha$-amylase activity 1.1 -fold in the absence of added xylose, which was relatively less than that of $P$. furiosus PPIase. In archaea, chaperone prefoldins can capture misfolded proteins and deliver them to Type II chaperonin for ATP-dependent folding, and the affinity of prefoldins to chaperonin influences the delivery efficiency $[19,39]$. The interaction of M. jannaschii prefoldins and type I chaperonin (B. subtilis) may be relatively low and influence the delivery efficiency, which demonstrates that chaperones may be co-expressed with their synergistic chaperones to sufficiently function.

Besides the above strategy to convert inclusion bodies to soluble form through improving the intracellular folding state, the strategy of heat treatment was applied subsequently. Since P. furiosus $\alpha$-amylase is natively produced within a hyperthermophilic environment $\left(\sim 100^{\circ} \mathrm{C}\right)$ and possesses a high level of molecular rigidity, and as its denaturation requires considerable energy $(316 \mathrm{~kJ} / \mathrm{mol})$, the correct folding of $P$. furiosus a-amylase may need a high level of energy [7, 40, 41]. Moreover, $P$. furiosus $\alpha$-amylase is prone to aggregate for its high hydrophobic characteristic, and a substantial portion of $P$. furiosus $\alpha$-amylase has been synthesized in $72 \mathrm{~h}$ as an inclusion body that slowly unfolded to the export-competent state and secreted into the extracellular space. The heat treatment of intact $\mathrm{CB}$ may promote this process through providing kinetic energy. Heat treatment at $90^{\circ} \mathrm{C}$ for 15 min was shown to be enough for heat activation, demonstrating that the refolding of intracellular $P$. furiosus $\alpha$-amylase at high temperature occurred much more quickly, which was consistent with the previous report [40]. Previous study showed that secretory expression of $P$. furiosus $\beta$-glucosidase in Saccharomyces cerevisiae was increased 4.4-fold by increasing the cultivation temperature from $30^{\circ} \mathrm{C}$ to $40^{\circ} \mathrm{C}$, and that the increased cultivation temperature promoted the folding and secretion of intracellular $\beta$-glucosidase [42]. The hypothesis was that the structure characteristics of hyperthermophilic proteins including more salt bridges in the multimer interfaces than the mesophilic analogues hinder the correct folding at low temperature, yielding accumulation of misfolded bodies [43]. Therefore, it seems that the poor folding of hyperthermophilic proteins in mesophilic host strains may share some common reasons for their similar structure characteristics, of which the heat treatment might have a commonly positive effect.

The ultrasonic disruption of the bacterial cell was too harsh and prevented the heat activation of cellular components, while the Bacterial Protein Extraction Kit disruption was mild and partly maintained the heat activation of cellular components. Compared with heat treatments of CM and BCS separately or CM and disruption components separately, heat treatment of intact $\mathrm{CB}$ shows the best activation effect. Meanwhile, the mold of heat treating intact $\mathrm{CB}$ was simple for application in industrial production and the yielded extracellular enzyme shows good storage stability at both $4^{\circ} \mathrm{C}$ and $25^{\circ} \mathrm{C}$.

The shake-flask culture conditions were optimized and included nitrogen source, carbon source, metal ion, fermentation temperature and $\mathrm{pH}$. The 3-L fermenter cultivation condition was then chosen on the base of shakeflask optimization. The highest activity obtained using the 3-L fermenter (3,806.7 U/ml after heat treatment) was 3.3-fold higher than that obtained prior to heat treatment $(1,155.1 \mathrm{U} / \mathrm{ml})$ and 28.2 -fold higher than that obtained using shake-flask cultivation $(135.1 \mathrm{U} / \mathrm{ml})$. This was also much higher than yields previously reported in E. coli $(11.4 \mathrm{U} /$ $\mathrm{ml})$ [12], B. amyloliquefaciens $(2,714 \mathrm{U} / \mathrm{ml})$ [13] and yeast $(220 \mathrm{U} / \mathrm{ml})[15]$.

In summary, the extracellular production of $P$. furiosus $\alpha$-amylase in $B$. subtilis was increased 1.2 -fold by coexpression of $P$. furiosus PPIase and 6.2 -fold through heat treatment at $90^{\circ} \mathrm{C}$ for $15 \mathrm{~min}$. After optimization of the culture conditions using shake-flask cultures, scale-up in a 3-L fermenter yielded the highest level of soluble, extracellular P. furiosus $\alpha$-amylase activity yet reported: $3806.7 \mathrm{U} / \mathrm{ml}$. These results demonstrate the effectiveness 
of thermophilic archaeal chaperone co-expression and heat treatment on hyperthermophilic protein production by $B$. subtilis. These simple methods may impact the starch processing industry and improve the production of other industrially useful enzymes.

\section{Acknowledgments}

This work received financial support from the National Key Research and Development Program of China (2019YFA0706900), the National Natural Science Foundation of China (31730067, 31901633), the Natural Science Foundation of Jiangsu Province (BK20180082), the National First-Class Discipline Program of Light Industry Technology and Engineering (LITE2018-03), the 111 Project (No. 111-2-06), and the Jiangnan University Postdoctoral Science Foundation (5818088201191160).

\section{Conflict of Interest}

The authors have no financial conflicts of interest to declare.

\section{References}

1. van der Maarel M, van der Veen B, Uitdehaag JCM, Leemhuis H, Dijkhuizen L. 2002. Properties and applications of starchconverting enzymes of the $\alpha$-amylase family. J. Biotechnol. 94: 137-155.

2. Richardson TH, Tan X, Frey G, Callen W, Cabell M, Lam D, et al. 2002. A novel, high performance enzyme for starch liquefaction. Discovery and optimization of a low pH, thermostable $\alpha$-amylase. J. Biol. Chem. 277: 26501-26507.

3. Khemakhem B, Ben Ali M, Aghajari N, Juy M, Haser R, Bejar S. 2009. Engineering of the a-amylase from Geobacillus stearothermophilus US100 for detergent incorporation. Biotechnol. Bioeng. 102: 380-389.

4. Saito N. 1973. A thermophilic extracellular a-amylase from Bacillus licheniformis. Arch. Biochem. Biophys. 155: 290-298.

5. Yuuki T, Nomura T, Tezuka H, Tsuboi A, Yamagata H, Tsukagoshi N, et al. 1985. Complete nucleotide sequence of a gene coding for heat- and $\mathrm{pH}$-stable $\alpha$-amylase of Bacillus licheniformis: comparison of the amino acid sequences of three bacterial liquefying $\alpha$ amylases deduced from the DNA sequences. J. Biochem. 98: 1147-1156.

6. Violet M, Meunier JC. 1989. Kinetic study of the irreversible thermal denaturation of Bacillus licheniformis a-amylase. Biochem. J. 263: 665-670.

7. Straub CT, Counts JA, Nguyen DMN, Wu CH, Zeldes BM, Crosby JR, et al. 2018. Biotechnology of extremely thermophilic archaea. FEMS Microbiol. Rev. 42: 543-578.

8. Adams MW. 1993. Enzymes and proteins from organisms that grow near and above 100 degrees C. Annu. Rev. Microbiol. 47: 627-658.

9. Demiriian DC, Moris-Varas F, Cassidy CS. 2001. Enzymes from extremophiles. Curr. Opin. Chem. Biol. 5: 144-151.

10. Laderman KA, Asada K, Uemori T, Mukai H, Taguchi Y, Kato I, et al. 1993. a-amylase from the hyperthermophilic archaebacterium Pyrococcus furiosus. Cloning and sequencing of the gene and expression in Escherichia coli. J. Biol. Chem. 268: 24402-24407.

11. Dong G, Vieille C, Savchenko A, Zeikus JG. 1997. Cloning, sequencing, and expression of the gene encoding extracellular $\alpha$-amylase from Pyrococcus furiosus and biochemical characterization of the recombinant enzyme. Appl. Environ. Microbiol. 63: 3569-3576.

12. Shen W. 2003. Expression of $\alpha$-amylase from Pyrococcus furiosus in different host cells. Doctor thesis. Jiangnan University.

13. Wang P, Wang P, Tian J, Yu X, Chang M, Chu X, et al. 2016. A new strategy to express the extracellular $\alpha$-amylase from Pyrococcus furiosus in Bacillus amyloliquefaciens. Sci. Rep. 6: 22229.

14. Harwood CR, Cranenburgh R. 2008. Bacillus protein secretion: an unfolding story. Trends Microbiol. 16: 73-79.

15. Wei Y, Wang R, Du L, Lu J, Huang K, Huang R. 2005. Secreted expression of synthesized hyperthermophilic $\alpha$-amylase gene $p f a$ in Pichia pastoris. J. Chin. Biotechnol. 25: 65-69.

16. Horwich AL. 2013. Chaperonin-mediated protein folding. J. Biol. Chem. 288: 23622-23632

17. Hartl FU, Hayer-Hartl M. 2002. Protein folding - Molecular chaperones in the cytosol: from nascent chain to folded protein. Science 295: $1852-1858$.

18. Skjærven L, Cuellar J, Martinez A, Valpuesta JM. 2015. Dynamics, flexibility, and allostery in molecular chaperonins. FEBS Lett. 589: 2522-2532.

19. Zako T, Murase Y, Iizuka R, Yoshida T, Kanzaki T, Ide N, et al. 2006. Localization of prefoldin interaction sites in the hyperthermophilic group II chaperonin and correlations between binding rate and protein transfer rate. J. Mol. Biol. 364: 110-120.

20. Martín-Benito J, Boskovic J, Gómez-Puertas P, Carrascosa JL, Simons CT, Lewis SA, et al. 2002. Structure of eukaryotic prefoldin and of its complexes with unfolded actin and the cytosolic chaperonin CCT. EMBO J. 21: 6377-6386.

21. Whitehead TA, Boonyaratanakornkit BB, Höllrigl V, Clark DS. 2007. A filamentous molecular chaperone of the prefoldin family from the deep-sea hyperthermophile Methanocaldococcus jannaschii. Protein Sci. 16: 626-634.

22. Glover DJ, Clark DS. 2015. Oligomeric assembly is required for chaperone activity of the filamentous $\gamma$-prefoldin. FEBS J. 282: 2985-2997.

23. Jakob RP, Koch JR, Burmann BM, Schmidpeter PA, Hunkeler M, Hiller S, et al. 2015. Dimeric structure of the bacterial extracellular foldase PrsA. J. Biol. Chem. 290: 3278-3292.

24. Ideno A, Yoshida T, Iida T, Furutani M, Maruyama T. 2001. FK506-binding protein of the hyperthermophilic archaeum, Thermococcus sp. KS-1, a cold-shock-inducible peptidyl-prolyl cis-trans isomerase with activities to trap and refold denatured proteins. Biochem. J. 357: 465-471.

25. Maruyama T, Suzuki R, Furutani M. 2004. Archaeal peptidyl prolyl cis-trans isomerases (PPIases) update 2004. Front. Biosci. 9: $1680-1720$.

26. Peng S, Chu Z, Lu J, Li D, Wang Y, Yang S, et al. 2016. Co-expression of chaperones from P. furiosus enhanced the soluble expression of the recombinant hyperthermophilic a-amylase in E. coli. Cell Stress Chaperon. 21:477-484.

27. Linden A, Niehaus F, Antranikian G. 2000. Single-step purification of a recombinant thermostable $\alpha$-amylase after solubilization of the enzyme from insoluble aggregates. J. Chromatogr. B. 737: 253-259.

28. Wang L, Zhou Q, Chen H, Chu Z, Lu J, Zhang Y, et al. 2007. Efficient solubilization, purification of recombinant extracellular aamylase from Pyrococcus furiosus expressed as inclusion bodies in Escherichia coli. J. Ind. Microbiol. Biotechnol. 34: 187-192.

29. Su Y, Liu C, Fang H, Zhang D. 2020. Bacillus subtilis: a universal cell factory for industry, agriculture, biomaterials and medicine. Microb. Cell Fact. 19: 173.

30. Zhang K, Su L, Wu J. 2020. Recent advances in recombinant protein production by Bacillus subtilis. Annu. Rev. Food Sci. Technol. 11: 295-318.

31. Zhang K, Su L, Wu J. 2018. Enhanced extracellular pullulanase production in Bacillus subtilis using protease-deficient strains and optimal feeding. Appl. Microbiol. Biotechnol. 102: 5089-5103.

32. Zhang K, Duan X, Wu J. 2016. Multigene disruption in undomesticated Bacillus subtilis ATCC 6051a using the CRISPR/Cas9 system. Sci. Rep-UK. 6: 27943 
33. Wenzel M, Müller A, Siemann-Herzberg M, Altenbuchner J. 2011. Self-inducible Bacillus subtilis expression system for reliable and inexpensive protein production by high-cell-density fermentation. Appl. Environ. Microbiol. 77: 6419-6425.

34. Anagnostopoulos C, Spizizen J. 1961. Requirements for transformation in Bacillus subtilis. J. Bacteriol. 81: 741-746.

35. Peters JM, Colavin A, Shi H, Czarny TL, Larson MH, Wong S, et al. 2016. A comprehensive, CRISPR-based functional analysis of essential genes in bacteria. Cell 165: 1493-1506.

36. Westers H, Westers L, Darmon E, van Dijl JM, Quax WJ, Zanen G. 2006. The CssRS two-component regulatory system controls a general secretion stress response in Bacillus subtilis. FEBS J. 273: 3816-3827.

37. Caspers M, Brockmeier U, Degering C, Eggert T, Freudl R. 2010. Improvement of Sec-dependent secretion of a heterologous model protein in Bacillus subtilis by saturation mutagenesis of the $\mathrm{N}$-domain of the AmyE signal peptide. Appl. Microbiol. Biotechnol. 86: $1877-1885$.

38. Freudl R. 2018. Signal peptides for recombinant protein secretion in bacterial expression systems. Microb. Cell Fact. 17: 52.

39. Ohtaki A, Kida H, Miyata Y, Ide N, Yonezawa A, Arakawa T, et al. 2008. Structure and molecular dynamics simulation of archaeal prefoldin: the molecular mechanism for binding and recognition of nonnative substrate proteins. J. Mol. Biol. 376: 1130-1141.

40. Brown I, Dafforn TR, Fryer PJ, Cox PW. 2013. Kinetic study of the thermal denaturation of a hyperthermostable extracellular $\alpha$ amylase from Pyrococcus furiosus. BBA-Proteins Proteom. 1834: 2600-2605.

41. Beadle BM, Baase WA, Wilson DB, Gilkes NR, Shoichet BK. 1999. Comparing the thermodynamic stabilities of a related thermophilic and mesophilic enzyme. Biochemistry 38: 2570-2576.

42. Smith JD, Richardson NE, Robinson AS. 2005. Elevated expression temperature in a mesophilic host results in increased secretion of a hyperthermophilic enzyme and decreased cell stress. Biochim. Biophys. Acta 1752: 18-25.

43. Szilágyi A, Závodszky P. 2000. Structural differences between mesophilic, moderately thermophilic and extremely thermophilic protein subunits: results of a comprehensive survey. Structure 8: 493-504.

44. Zhang K. 2018. Modification of Bacillus subtilis strain, promoter optimization and high-level expression of pullulanase. Doctor thesis. Jiangnan University. 